\title{
Water Demand Analysis for Tree Crops in Spanish Mediterranean Farms
}

\author{
Maria Angeles Fernández-Zamudio ${ }^{1 *}$, Maria Dolores De-Miguel² \\ and Pedro Caballero'
}

${ }^{1}$ Departamento de Economía y Sociología Agrarias, Instituto Valenciano de Investigaciones

Agrarias, Apartado Oficial s/n. 46113 Moncada (Valencia), Spain.

${ }^{2}$ Departamento de Economía de la Empresa, Universidad Politécnica de Cartagena,

Paseo Alfonso XIII, 44. 30203 Cartagena (Murcia), Spain.

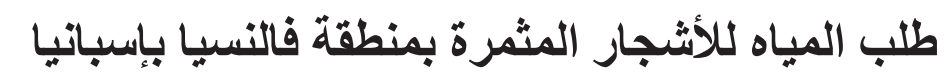

$$
\text { ماريا أنجلز فرنندز-ز اموديو وماريا دولورس دي ميجال وبادرو كابابارو }
$$

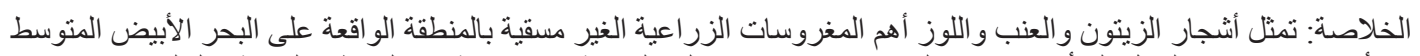

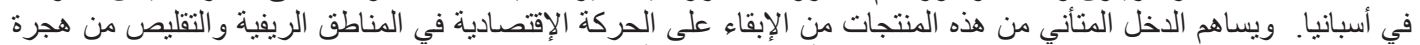

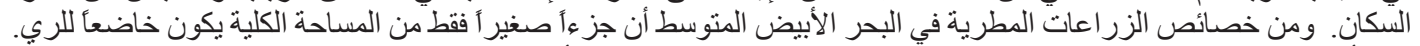

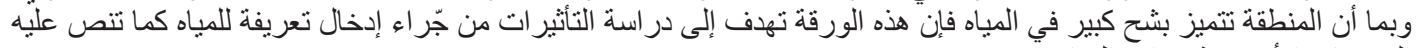
التوجهات الأوروبية لإدارة المياه.

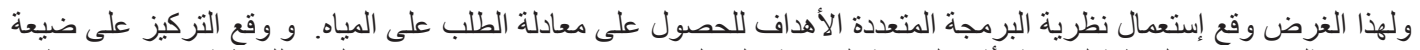

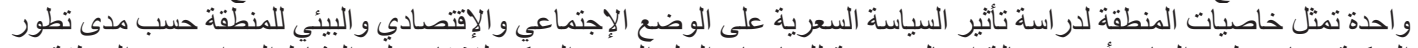

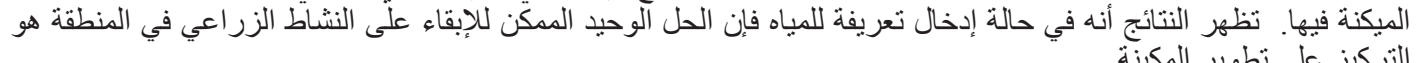

ABSTRACT: Olive, vine and almond in rainfed farming systems are the most traditional crops in the large inland extensions of the Spanish Mediterranean. Their economic contributions enable farming activities to be maintained meaning that the villages remain inhabited. In the rainfed-farms in the Mediterranean regions it is possible to find only a certain proportion of the farms with some type of irrigation system. Given the water scarcity, the aim of this work is to determine the impact that an irrigationwater pricing policy would have on these regions, as outlined in the European Water Framework Directive. After analysing the direct effect water price would have on the net margin in these crops, demand functions have been obtained, applying the Multiattribute Utility Theory. The calculations, with reference to a farm that is representative of these regions, have been applied to two model scenarios, each with a different level of mechanization. Results show the impact on economic, social and environmental aspects of the pricing policy under the current water allotment. The work is completed by analysing the different contexts of irrigation-water availability on the farm. The study leads to the conclusion that increasing mechanization may be the most straightforward strategy to ensure the survival of these farms in the short to medium term if the current trend of increasing irrigation-water prices is consolidated.

Keywords: Mediterranean agro-systems, Multiattribute Utility Theory, demand functions of irrigation water, olive, vine, almond.

\section{Introduction}

Mediterranean rainfed-farming is predominant in the inland parts of Spain. The most traditional and characteristic crops are the olive (Olea europea L.), the vine (Vitis vinifera L.) and the almond (Prunus dulcis Mill.) combined in different proportions on the 
Table 1. Crop-growing activities: description, annual water supply and net margin for two production prices.

\begin{tabular}{|c|c|c|c|c|c|}
\hline \multirow{2}{*}{$\begin{array}{l}\text { Species } \\
\text { Varieties } \\
\text { Irrigation }\end{array}$} & \multicolumn{2}{|c|}{$\begin{array}{c}\text { Olive } \\
\text { Grossal } \\
\text { Authochthonous }\end{array}$} & \multirow{2}{*}{$\begin{array}{c}\begin{array}{c}\text { Almond } \\
\text { Comuna Group } \\
\text { Authochthonous }\end{array} \\
\text { Irrigated relief }\end{array}$} & \multicolumn{2}{|c|}{$\begin{array}{c}\text { Vine } \\
\text { Monastell } \\
\text { Tube }\end{array}$} \\
\hline & $\begin{array}{r}\text { Irrigated } \\
\text { relief } \\
\end{array}$ & Irrigated & & $\begin{array}{r}\text { Irrigated } \\
\text { relief }\end{array}$ & Irrigated \\
\hline Variable & 0-Ir & $0-1$ & A-Ir & V-Ir & V-I \\
\hline Annual water supply $\left(\mathrm{m}^{3} / \mathrm{ha}\right)$ & 700.00 & 1500.00 & 700.00 & 1100.00 & 1500.00 \\
\hline Production (kg/ha) & 3000.00 & 5000.00 & 1400.00 & 7000.00 & 1000.00 \\
\hline Price-1 (euros/kg) & 0.66 & 0.66 & 0.66 & 0.35 & 0.35 \\
\hline Net margin-1 (euros/ha) $(*)$ & 1075.00 & 2056.00 & 264.00 & 1219.00 & 2138.00 \\
\hline Price-2 (euros/kg) & 0.56 & 0.56 & 0.56 & 0.30 & 0.30 \\
\hline Net margin-2 (euros/ha) $(*)$ & 778.00 & 1560.00 & 125.00 & 853.00 & 1615.00 \\
\hline
\end{tabular}

Source: own calculations.

$\left(^{*}\right)$ Net margins of zero value of irrigation water.

majority of farms. The three woody species are grown extensively and frequently with minimal management; in other words, with semi-abandonment in which these three tree crops are left to survive at the mercy of the climate. These crops have helped in maintaining the countryside, which is one of the landmarks of the cultural identity of these regions, in protecting the soil from erosion, and they can also be considered an important promoter of human activity.

Although agriculture has traditionally supplied the main income to the population, socioeconomic changes have led to transformation of the farming communities in the Mediterranean inland regions. The industrial and the service sectors continue to put strong pressure on labour resources, especially among young people giving little incentive to continue farming activities which limits generational take-over and leads to the disappearance of family farms.

In the arid regions of the Mediterranean, agriculture is strongly influenced by the irregularity of rainfall. The most important natural resource is water, which is in short supply and of the greatest value. The availability of water for irrigation considerably increases yield, assures a greater regularity in harvest and decreases the economic risks in farming. On the other hand, the current European Water Framework Directive proposes an irrigation water pricing policy to improve the efficient use of this resource. However, high water prices would reduce the profitability of the farms and could affect the continuity of this type of agriculture.
The present paper is conceived with the general goal of determining the impact that an irrigation-water pricing policy would have in the arid Mediterranean regions. The work starts off by calculating the direct effect of water cost on the net margin and goes on to determine the demand functions of water by applying Multiattribute Utility Theory for different contexts of the irrigation-water availability on the farm.

\section{Direct Impact of Irrigation Water on Incomes}

A first approach to assessing the impact of irrigation water on incomes can be obtained by observing the reduction in the net margin of each crop according to the increase in the price of this resource (CastroCoelho et al., 2005). In this section we are going to analyse the effect of water price on incomes from olive, vine and almond in a representative region in the Spanish inland L'Alcoià, in the province of Alicante. We have only taken the five main activities that receive some kind of irrigation.

Table 1 shows the average productions and the usual volume of irrigation. Two net margins have been calculated. The net- 1 margin is according to the average price of the harvest received by the farmers in the zone analysed over the last five years. The net- 2 margin corresponds to a price $15 \%$ lower than the first, to simulate the effect if the clear downward trend in the prices of these three species continues. These crops display high irrigation efficiency. Their production increases notably even when the volumes applied are very low. The greatest problem is the low profit, especially given the trend of decreasing prices received 


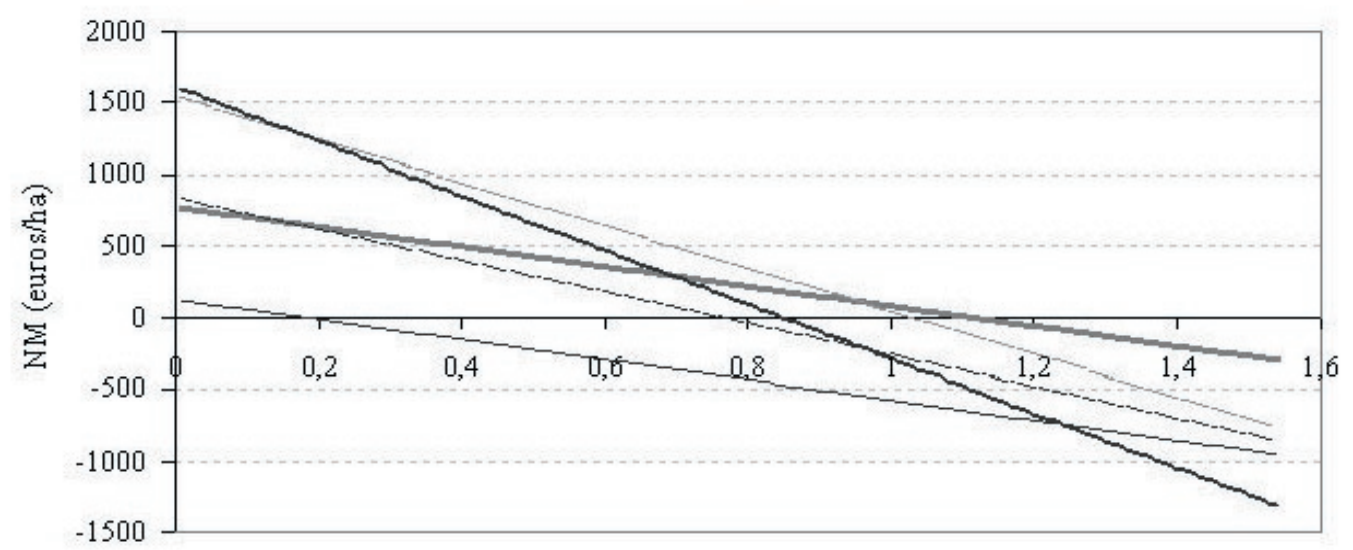

Price of irrigation water $\left(\right.$ euros $\left./ \mathrm{m}^{3}\right)$

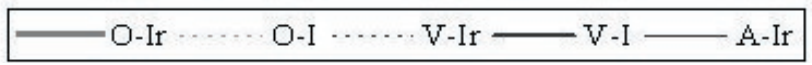

Figure 1. Crops net margin changes according to irrigation water price. (Data for net margin-1).

by the farmers for the harvest; thus any increase in the costs could reduce their profitability even more.

In order to observe the direct effect of the price of irrigation water on the net margin, we present Figures 1 and 2. For the almond, negative margins start to occur at a price of 0.37 euros $/ \mathrm{m}^{3}$ (to price-1) and of only 0.17 euros $/ \mathrm{m}^{3}$ at price-2, which implies a reduction of 54 $\%$ in growing capacity to face the cost of water. For the vine, the negative net margins are found for water prices of 1.11 or 1.13 euros $/ \mathrm{m}^{3}$ (for price -1 ), and 0.77 or 0.85 euros $/ \mathrm{m}^{3}$ if the harvest is sold at price- 2 , which implies a reduction of 25 or $31 \%$. Finally, the olive would have a negative net margin if the water costs 1.53 or 1.36 euros $/ \mathrm{m}^{3}$, but if the olive is paid for at price-2 the margin would be negative when the water costs 1.11 or 1.04 euros $/ \mathrm{m}^{3}$. This implies a reduction of 23 or $27 \%$ when dealing with the species that has the greatest margin to offset the high water prices.

The price levels of irrigation water that this agriculture could withstand can be determined more thoroughly via demand curves, which are presented in the following section.

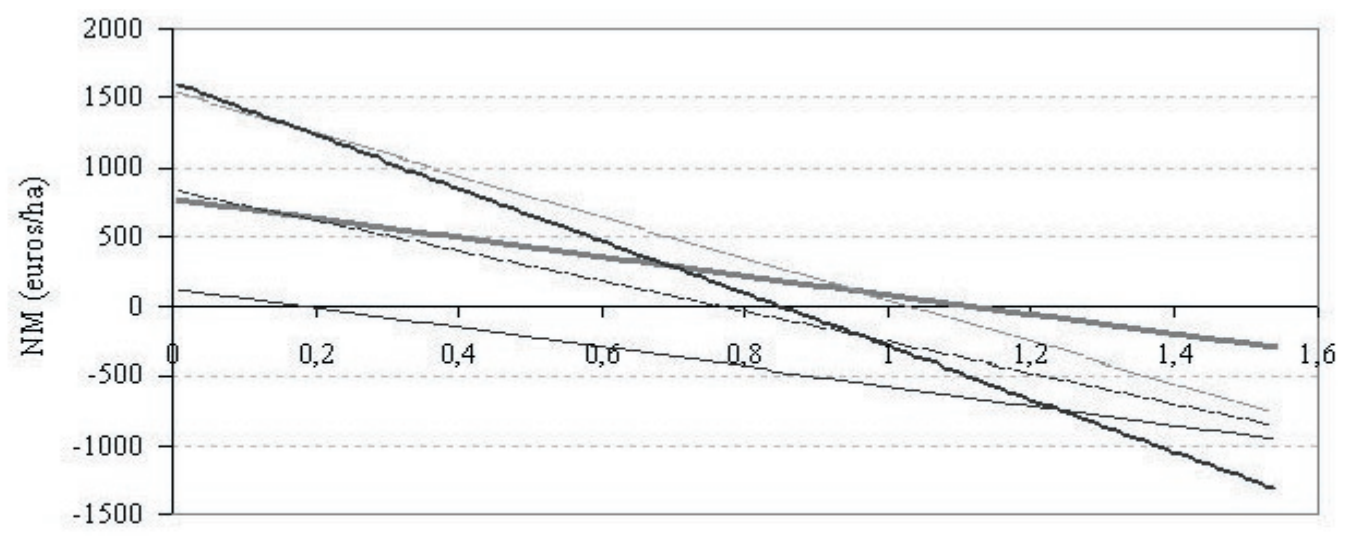

Price of irrigation water (euros $/ \mathrm{m}^{3}$ )

$$
\longrightarrow \text { O-Ir } \cdots . . . \text { O-I } \cdots \cdots \cdot \text { V-Ir } \longrightarrow \text { V-I } \longrightarrow \text { A-Ir }
$$

Figure 2. Crops net margin changes according to irrigation water price. (Data for net margin-2). 


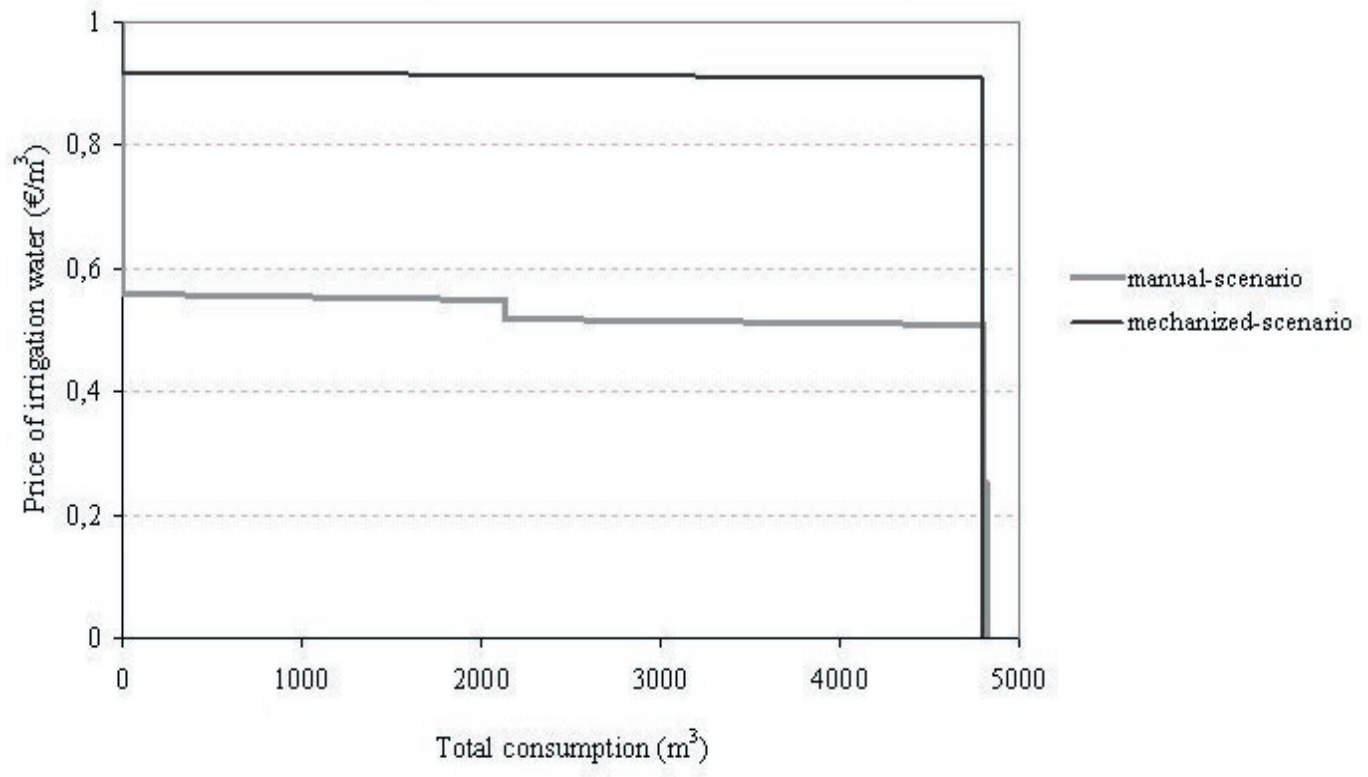

Figure 3. Demand functions for irrigation water for the two scenarios. (Data for a family farm of 32 hectares).

\section{Irrigation Water Demand Functions}

On approving the Water Framework Directive (Directive 2000/60/EC), the European Parliament set a number of actions regarding water policy at the Community level (Official Journal, 2000). This Directive, with a clear environmental focus, established the convenience of using pricing as an economic tool to increase the efficient use of water, proposing the achievement of full-cost recovery of water by 2010. It is difficult to find an appropriate method to achieve this objective directly, but it is possible to find an approximation of farmers' response in the event of applying a water-pricing policy by using the neoclassical Economic Theory, and especially the Multiattribute Utility Theory (MAUT). Several previous workers pointed out the suitability of using the Multiattribute Utility Theory to derive demand functions, (Berbel and Gómez-Limón, 2000; GómezLimón and Riesgo, 2004).

The work by Keeney and Raiffa (1976) is a starting point of MAUT. Later Edwards (1977), Farmer (1987) and Huirne and Hardaker (1998) went on to perfect it. We have followed the framework developed by Sumpsi et al. (1996) and Amador et al. (1998). The objective is to find the utility function, $U$, separable, additive and linear for each attribute, $f_{i}(x)$, which once normalized would be:

$$
U=\sum_{i=1}^{n} w_{i} \frac{f_{i}(x)-f_{i^{*}}}{f_{i}^{*}-f_{i^{*}}}
$$

where $w_{i}$ are the weights obtained previously, $f_{i}^{*}$ is the ideal value for each objective and $f_{i^{*}}$ worst or anti-ideal, which are extracted from the pay-off matrix.

We determined the utility function of a farm representative of the region under study. A series of simulations are made with rising prices of irrigation water, in such a way that each price is a new scenario in which utility is maximized, and from which we derive a cropping plan with a specific demand for irrigation water.

The simulation models are applied to two scenarios related to the degree of mechanization on-farm. In the "manual-scenario", low-powered mobile equipment was used together with traditional harvesting and hand-picking. In the "mechanized-scenario" we consider higher-powered mobile equipment, together with the use of pre-pruners, harvesting with integral grape-collectors in the vines, and automatic vibrators with mechanized picking and fruit loading systems for the olives and the almonds. The most expensive 


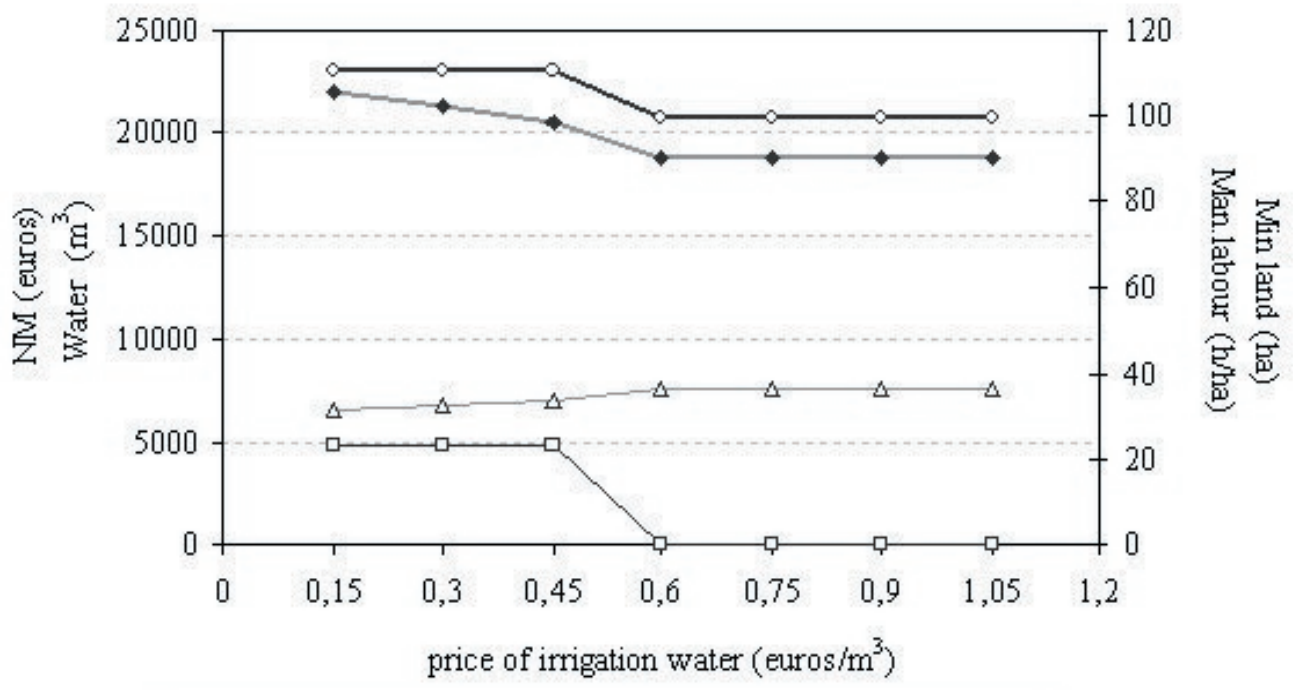

Figure 4. Repercussions derived from the application of a water pricing policy. (Data for 32 hectares). Manual scenario.

machinery is always considered to be rented, so that its high amortization does not prevent farmers with less available capital from adopting its use.

The decision variables are the surface area in exploitation for each crop-growing activity. Olive and almond (an autochthonous variety and a new variety) and vine (in tube or espalier) have been introduced.
In total, 16 decision variables are considered, the main difference being the amount of irrigation water applied. We contemplate the option of complementary irrigation and, in the case of the vine and olive ,conventional drip irrigation is also possible, with greater and more continuous flow.

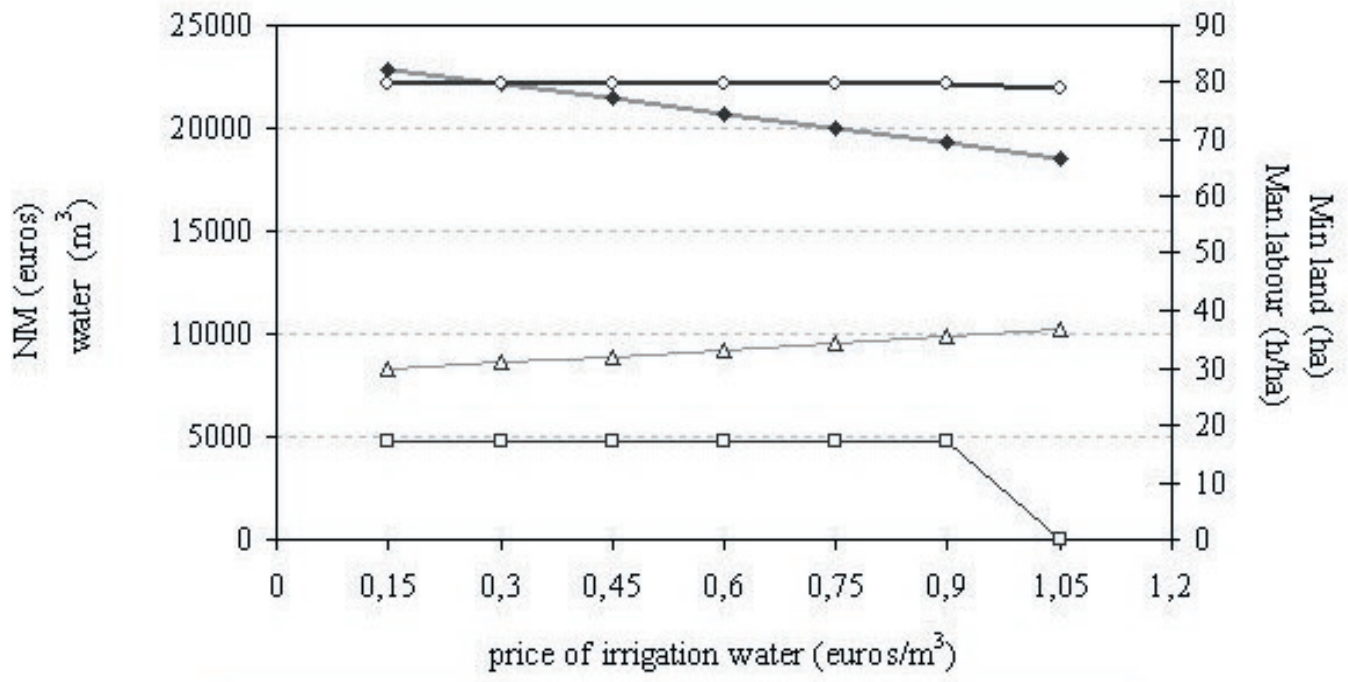

$\rightarrow$ total NM $\rightarrow-$ total water $\hookrightarrow-$ Min.land $\multimap-$ manual labour

Figure 5. Repercussions derived from the application of a water pricing policy. (Data for 32 hectares). Mechanizedscenario. 


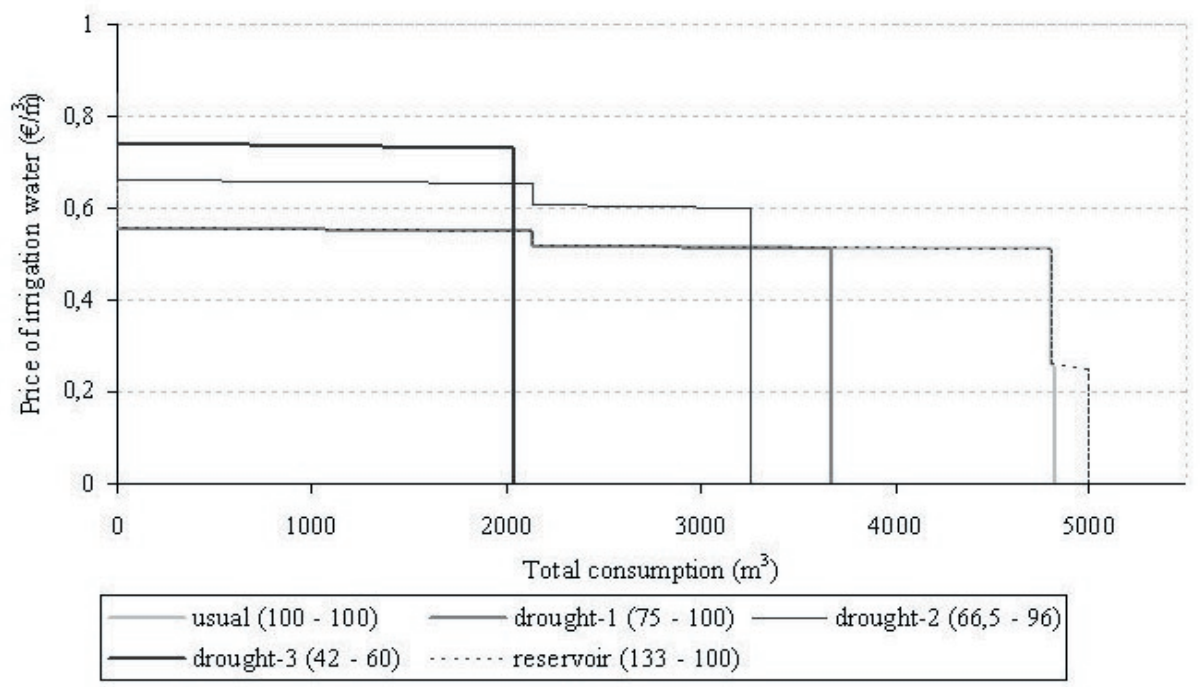

Figure 6. Water demand function for different water allotment and prices, "manual-scenario". (Data for 32 hectares).

The following objectives are considered: maximization of the net margin of the farm and minimization of the total workforce. A number of restrictions have been taken into account, and have been considered equally in both scenarios: [1] Crop area (a total of 32 hectares are available on the farm). [2] Marginal management (at maximum $30 \%$ of the available surface area). [3] The maximum surface area of each species is limited to its present situation ( $32 \%$ in olive, $8 \%$ in almond and $60 \%$ in vine) since we are dealing with tree crops and the models under consideration are static. However, changes in variety within a species, changes in the type of irrigation, or for this to pass to marginal management are allowed. [4] Irrigated surface area: only $10 \%$ of the available surface area can receive some kind of irrigation, according to the criteria of the experts consulted. [5] Manual labour and family labour is fixed at an Agricultural Work Unit (2,160 hours a year), and hired labour is limited to complement what cannot be covered by family on a three-monthly basis.

\section{Demand Functions: Results and Discussion}

With respect to the availability of irrigation, water supplied cannot exceed $600 \mathrm{~m}^{3}$ monthly for the whole farm, and the total amount allotted to the farm is 5,000 $\mathrm{m}^{3}$ annually. The demand curve obtained is shown in Figure 3. In the "manual scenario" there is a first range of maximum demand, between 0 and 0.51 euros $/ \mathrm{m}^{3}$. This continues with a drop to half the demand for tariffs of 0.52 a 0.55 euros $/ \mathrm{m}^{3}$ and ends up with cropping plans in completely rainfed-farming when the water costs over 0.56 euros $/ \mathrm{m}^{3}$. In the "mechanized scenario" the demand is constantly at maximum until it reaches 0.91 euros $/ \mathrm{m}^{3}$, at which point the chosen cropping plan changes to strict rainfed-farming. The different response must be looked for in the different degree of mechanization. Technology improves management and enables farmers to substitute the labour requirements that arise from irrigated crops more effectively. This limitation is accentuated if the work, especially harvesting, is carried out manually. For this reason, the mechanized farms are more able to pay higher water prices.

Cropping plans are obtained for each water price simulated. Each of them generates a net margin on the farm, labour requirements and water consumption. It is also possible to calculate another indicator from the surface area of land necessary to achive a minimum income, for example 21,500 euros. All these indicators help in understanding the economic, social, and environmental repercussions of a hypothetical irrigation water pricing policy in these regions. Figures 4 and 5 show the variation in the same area for six price levels that are higher than the current ones, taking into account that the usual cost of irrigation water in this region is 0.15 euros $/ \mathrm{m}^{3}$.

For the "manual scenario" (Figure 4), in line with the increase in water prices, there is a decrease in the income, water consumption and the manual labour 

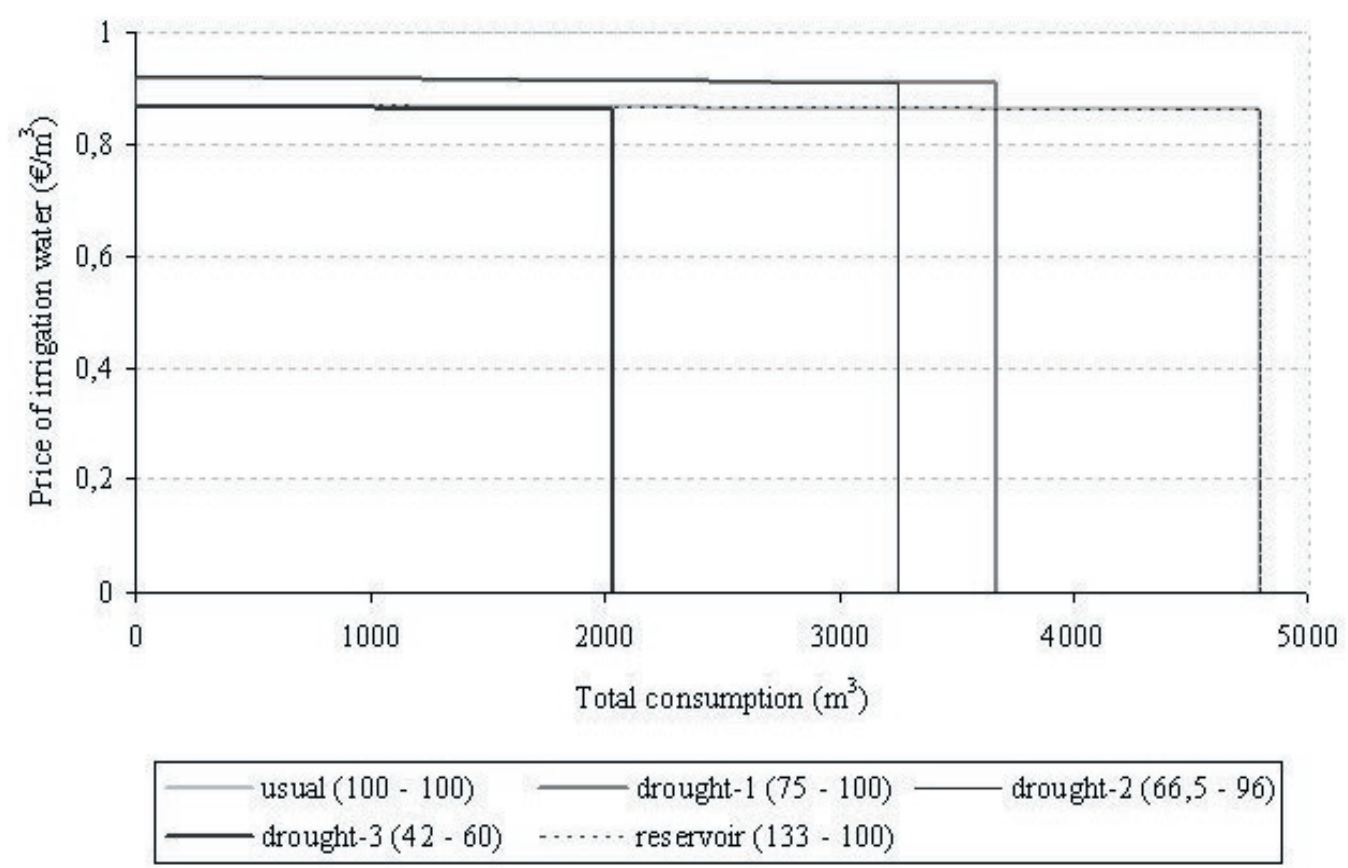

Figure 7. Water demand function for different water allotment and prices, "mechanized-scenario". (Data for 32 hectares).

demanded. For a price above 0.24 euros $/ \mathrm{m}^{3}$, an income below the minimum is obtained, and over 0.51 euros/ $\mathrm{m}^{3}$ a totally rainfed cropping plan is adopted. Without irrigation, the net margin of the farm is 18,810 euros, employing an average of 100 hours manual work annually per cultivated hectare. At the present price of water, the minimum income is obtained by cultivating 31.3 ha, but 36.6 ha are needed if cultivation is totally rainfed.

In Figure 5 we can observe the effects on a farm for the "mechanized scenario". The cropping plan includes irrigation until the price of irrigation water is lower or equal to 0.91 euros $/ \mathrm{m}^{3}$. Above that price the farm plan converts to rainfed cultivation. The income decreases gradually with the rise in the cost of water, and the minimum income is not assured if the price of water is over 0.4 euros $/ \mathrm{m}^{3}$. With the present price of water, the minimum income is obtained by cultivating 30 ha, but in the case of the strict rainfed cultivation 37 ha are necessary to ensure the minimum income. The high stability in manual-work requirements is notable, which is practically 80 hours annually per hectare for all water prices.

The analysis of irrigation-water demand is completed by evaluating, in addition to the present context, different scenarios of resource availability on the farm. In the usual scenario the farm has 600 $\mathrm{m}^{3}$ monthly and $5,000 \mathrm{~m}^{3}$ annually. These reference values are denominated as "usual $(100-100)$ ". Three drought scenarios are evaluated, in which there can be a monthly or annual reduction, in terms of the percentage with respect to the habitual, named as "drought-1 (75100)", "drought-2 (66,5 - 96)" and "drought-3 (42 - 60)". Finally, we contemplate the possibility of having a reservoir on the farm, with which the monthly availability would increase, although not annually. This would be "reservoir (133 - 100)".

The demand curves obtained in new contexts of water availability on the farm show the differences between both initial model scenarios. In the "manual scenario" (Figure 6), several different cropping plans are generated, ranging between the situation consuming the whole water allotment and that chosen for rainfed cultivation. For the "mechanized scenario" (Figure 7), the same cropping plan is obtained if water is available. Only when the price of irrigation becomes too high $\left(0.87 € / \mathrm{m}^{3}\right)$ does the cropping plan change to total rainfed cultivation. These results confirm how mechanization reinforces in its turn the efficiency of irrigation. The fact that the same activities are 
chosen, independently of water price, is because the good level of mechanization enables a choice of the most productive varieties, although they demand more manual labour.

On the other hand, in conditions of drought, the model shows that farmers will be willing to pay more for the water. This is observed graphically, for example, in the "manual scenario" (Figure 6), at 0.56 euros $/ \mathrm{m}^{3}$ rainfed farming would be the option; on moving to the availability corresponding to drought- 3 , irrigation is continued up to a price of 0.74 euros $/ \mathrm{m}^{3}$. Nevertheless, this affirmation should not lead to overvaluing the capacity of this agrarian system, since the increase in price that the farm can face is not proportional to reduction in supply that it is subjected to. For a reduction of $58 \%$ in the monthly water allotment and $40 \%$ in the annual one, between the "manual scenario" and that of drought- 3 , the difference in price is only $32 \%$. Similar conclusions can be drawn from the "mechanized scenario", even though the most efficient activities are chosen from the first moment. In this case, a situation of extreme drought will not generate enough income to compensate higher costs of machinery, and therefore the crop plan will be totally rainfed for water prices over $0.87 € / \mathrm{m}^{3}$ (drought-3), or over $0.91 € / \mathrm{m}^{3}$ (in drought- 1 and drought-2).

\section{Conclusion}

In evaluating the direct impact of water price on the net margins the olive tree is the species that can justify higher irrigation water prices. With respect to the different demand functions derived, results show that the effect of water price on the farmers' income is that a higher degree of mechanization is necessary in order to face the high irrigation-water prices. The current price of water is 0.15 euros $/ \mathrm{m}^{3}$ and it could increase. However, to ensure a minimum income for the farm of 21,500 euros annually, water price cannot exceed 0.24 euros $/ \mathrm{m}^{3}$ on a manual farming system, or $0.4 \mathrm{euros} / \mathrm{m}^{3}$ if the farm is mechanized.

In situations of drought, the farming system cannot proportionally face a reduction in the allotment with higher irrigation-water prices. In any event, to ensure the survival of the farms in the Spanish rainfed farming system increasing mechanization is the most straightforward strategy. This is to guarantee the viability of this agriculture if the current trend of increasing irrigation-water prices continues. Mechanization should be on a rent basis and not on an ownership basis to make it affordable.

\section{Acknowledgements}

The present paper forms part of Research Project AGL 2002-04251-C03-01, financed by the Spanish Ministry of Finance and Technology and FEDER funds.

\section{References}

Amador, F., J.M. Sumpsi and C. Romero. 1998. A non-interactive methodology to assess the farmers' utility function: An application to large farms in Andalusia, Spain. European Review of Agricultural Economics 25:95-109.

Berbel, J. and J.A. Gómez-Limón. 2000. The impact of water-pricing policy in Spain: an analysis of three irrigated areas. Agricultural Water Management 43:219-238.

Castro-Cohelo, J., L.M. Silva, M. Tristany and P. Pinto. 2005. Planning cropping systems for the new irrigation areas under the influence of the Alqueva dam. The case study of the Odivelas irrigation scheme. New Mediterranean 3:3-11.

Edwards, W. 1977. Use of Multiattribute Utility Measurement for Social Decision Making. D.E. Bell, R.L. Keeney, R.L. and H. Raiffa (Editors), Decisions. John Wiley \& Sons, New York.

Farmer, P.C. 1987. Testing the robustness of Multiattribute Utility Theory in an applied setting. Decision Sciences 18:178-193.

Gómez-Limón, J.A. and L. Riesgo. 2004. Water pricing: analysis of differential impacts on heterogeneous farmers. Water Resources Research 40:W07S05.

Huirne, R.B.M. and J.B. Hardaker. 1998. A multiattribute model to optimise sow replacement decisions. European Review of Agricultural Economics 25:488-205.

Keeney, R.L. and H. Raiffa. 1976. Decisions with Multiple Objectives: Preferences and Value Trade Offs. John Wiley \& Sons, New York.

Official Journal. 2000. Framework for community action in the field of water policy. Edition L, 327 of 22.12.2000. Available from URL [accessed $1 \mathrm{Nov}$ 2005]: http://europa.eu.int/scadplus/leg/en/lvb/ 128002b.htm

Sumpsi, J.M., F. Amador and C. Romero. 1996. On farmer's objectives: A multi-criteria approach. European Journal of Operational Research 96: 64-71. 